\title{
Inequality Impact of MSME Assistance in Indonesia on Urban Migration in the Post Pandemic Era
}

\author{
Nana Nurwaesari ${ }^{1, *}$ Putri Maulidiyah ${ }^{2}$, Dian May Fitri ${ }^{3}$ \\ ${ }^{1,2}{ }^{3}$ Postgraduate Student of School of Government and Public Policy Indonesia \\ *Corresponding author. Email: nana.nurwaesari@sgpp.ac.id
}

\begin{abstract}
Since the Covid-19 outbreak, MSMEs have become one of the most affected economic sectors. In August 2020, the Central Government of Indonesia officially launched a special program to help MSMEs namely the Direct Cash Assistance (DCA) amounting to 2.4 million rupiah, which later this amount reduced to 1.2 million rupiah in the early 2021. This study aims to recommend what things need to be prepared by policy makers if there is an increase in urban migration in Indonesia after pandemic era. The study uses two indicators in evaluating DCA Program namely the Distribution of Direct Cash Assistance, especially the distribution mechanism from government to the end users, and The Realization Number of Recipients by using the Objective-Oriented Evaluation Approach. In addition, the SWOT method is also used to analyze this DCA program. This research found that during August 2020 to March 2021, the distribution of assistance to MSME players in Eastern Indonesia was only reached 5 percent due to infrastructure constraints and incomplete database. In this finding, the researchers predict that there will be an increase of urban migration because the rising of unemployment and economic growth is still difficult to crawl up. Infrastructure constraints in remote areas in Indonesia encourage more people to migrate to urban areas in the post pandemic period.
\end{abstract}

Keywords: Pandemic Covid-19, Urban Migration, MSMEs, Direct Cash Assistance, Indonesia

\section{INTRODUCTION}

The presence of MSMEs in Indonesia is no longer in doubt. MSMEs play an important role in social, economic, and political roles. On the social aspect, MSMEs help someone to have access to a decent life. This self-worth can be achieved when an individual works and having a job, then indirectly the high absorption of labor by MSMEs helps the community to increase their self-worth [1]. On the political side, the rapid economic cooperation between countries, especially in the context of ASEAN and APEC, can create new opportunities for MSMEs [2].

Economically, MSMEs play a role as heroes in securing the Indonesian economy during the Asean Financial Crisis in 1997-1998 [3]. When the economic crisis hit developing countries such as Indonesia, small and medium enterprises or SMEs are a business group which could survive well [4]. This is evidenced by the high number of labor absorption in 1997 and 1998. Based on data from the Central Statistics Agency, the absorption of labor in 1997 by small entrepreneurs was the highest at 57.40 million $(87.62 \%)$. Then in 1998 , the number of employment by small entrepreneurs was also the highest at 57.34 million (88.66\%) [5]. In other words, MSMEs can help reduce poverty and unemployment, as well as suppress excess urban migration in big cities like Jakarta [1].

MSMEs are considered capable of saving the economy by taking advantage of the value of domestic transactions and encouraging MSME business development during the 1998 Asean Financial Crisis and the 2008 Global Crisis. However, MSMEs were in a very bad condition during the COVID-19 pandemic [6]. The policy of Large-scale Social Restrictions or Pembatasan Sosial Berskala Besar (PSBB) is one of the most significant differentiators during the COVID-19 pandemic. This policy did not exist in the Asean Financial Crisis and the Global Crisis, so MSMEs experienced difficulties that were much different from the two periods. Many micro-enterprises have had to close their businesses due to cash flow constraints [7].

\section{LITERATURE REVIEW}

In assisting the recovery of MSMEs during the COVID-19 pandemic, the Government issued Law no. 2 of 2020 and Government Regulation No. 23 of 2020 as 
the basis for organizing the National Economic Recovery Program. This program is expected to help MSMEs survive during the pandemic and improve the performance of MSMEs that contribute to the Indonesian economy. One of the assistances in this program is the Presidential Assistance for Productive Micro Enterprises (hereinafter referred to as Direct Cash Assistance Program) [6]. The Direct Cash Assistance Program is a cash assistance provided to MSME actors throughout Indonesia. This program launched on July 14,2020 which each recipient of this assistance received IDR 1.2 million whereas previously in 2020 each recipient received IDR 2.4 million [8].

The COVID-19 pandemic has had a tremendous impact on MSME actors, such as capital difficulties, decreased sales, and difficulty in obtaining raw materials [9]. Based on data from the Ministry of Cooperatives and SMEs, 37,000 Indonesian MSMEs were seriously affected by the pandemic, of which around 56 percent experienced a decline in sales, 22 percent faced financing problems, 15 percent had difficulty in distributing goods, and 4 percent had difficulty getting raw materials [10]. A survey conducted by the Asian Development Bank (ADB) shows that the condition of MSMEs in Indonesia is quite bad. As many as 88 percent of micro-enterprises reported having no savings and running out of money during the pandemic. In addition, as many as 39 percent of MSMEs depend on loans from relatives [11].

Based on these previous studies, the assistance that MSMEs really need includes money or business capital, because MSMEs are facing difficulties on liquidity. Meanwhile, the recovery of MSMEs does not only need to be carried out in the short term, but also in the medium and long term. This is because Indonesia is at risk of experiencing economic depression and unemployment for several years. What's more, equitable MSME assistance is necessary during the COVID-19 pandemic. Often growth and equity are two contradictory things. If development is focused on economic growth, equity will be ruled out, and vice versa [12]. This is to avoid an increase in urban migration in the post pandemic period.

\section{METHOD}

This study uses two methodologies, namely, literature study and in-depth interviews which conducted by researchers to several stakeholders involved in the Direct Cash Assistance (DCA) program during the COVID-19 pandemic in 2020 to 2021. Furthermore, the study uses two indicators in evaluating DCA Program namely the Distribution of Direct Cash Assistance, especially the distribution mechanism from government to the end users, and The Realization Number of Recipients by using the Objective-Oriented Evaluation Approach.
The Objectives-Oriented Evaluation Approach is a very suitable framework to assist the evaluators in evaluating the extent to which this program has achieved its objectives. Through this objective-oriented approach, evaluators can determine whether some or all of the program objectives are achieved and, if so, how well they are achieved. In addition, the DCA Program is also analyzed using the SWOT (Strength, Weaknesses, Opportunities, and Threats) method which aims to enable researchers to predict what things will emerge from the inequality impact of MSME Assistance in Indonesia in the future, especially on urban migration in the post-pandemic era.

\section{RESULT AND ANALYSIS}

\subsection{Inequality Distribution on DCA Program in Indonesia during COVID-19 Pandemic}

Based on the goals and targets, the DCA Program in 2020 and 2021 has the same target in distributing DCA assistance. Around 12.8 million MSMEs in Indonesia that have passed the selection as beneficiaries are eligible to receive IDR 1.2 million assistance.

The first indicator measured by the researchers is the mechanism for the distribution of Direct Cash Assistance, in which this distribution must be ensured to recipients who meet the main requirements, namely, MSME actors. The results of this study indicate that there are several layers in distributing DCA programs starting from the government, banks, to the end-users or DCA recipients. Previously, the only channeling bank was BRI Bank. Meanwhile, entering 2021, this aid distribution institution is increasing with the presence of BNI, Aceh Regional Development Bank and currently in the process with PT. POS for distribution of DCA in Eastern Indonesia.

Table 1. Distribution of Direct Cash Assistance Program to Indonesian MSMEs, 2021

\begin{tabular}{|c|l|c|}
\hline No. & \multicolumn{1}{|c|}{ Provinces } & $\begin{array}{r}\text { Number of } \\
\text { MSME recipients }\end{array}$ \\
\hline 1 & West Java & 2.402 .932 \\
\hline 2 & Central Java & 1.196 .424 \\
\hline $\mathbf{3}$ & East Java & 1.056 .208 \\
\hline 4 & North Sumatra & 565.987 \\
\hline $\mathbf{5}$ & DKI Jakarta & 440.821 \\
\hline 6 & West Nusa Tenggara & 363.266 \\
\hline 7 & South Sumatra & 310.383 \\
\hline 8 & Riau & 297.683 \\
\hline 9 & Banten & 290.079 \\
\hline 10 & South Sulawesi & 284.159 \\
\hline 11 & East Nusa Tenggara & 264.692 \\
\hline 12 & Bali & 239.469 \\
\hline 13 & West Sumatra & 223.564 \\
\hline 14 & Lampung & 221.517 \\
\hline 15 & East Kalimantan & 194.994 \\
\hline 16 & North Sulawesi & 189.902 \\
\hline 17 & Central Sulawesi & 176.721 \\
\hline
\end{tabular}




\begin{tabular}{|c|l|c|}
\hline 18 & South Kalimantan & 125.335 \\
\hline 19 & West Kalimantan & 117.642 \\
\hline 20 & Yogyakarta & 107.106 \\
\hline 21 & Jambi & 103.426 \\
\hline 22 & Bengkulu & 89.461 \\
\hline 23 & Aceh & 80.928 \\
\hline 24 & Bangka Belitung Islands & 68.724 \\
\hline 25 & Central Kalimantan & 61.053 \\
\hline 26 & West Sulawesi & 59.606 \\
\hline 27 & Riau Islands & 57.623 \\
\hline 28 & Gorontalo & 45.002 \\
\hline 29 & Maluku & 42.034 \\
\hline 30 & North Maluku & 40.316 \\
\hline 31 & Southeast Sulawesi & 37.485 \\
\hline 32 & Papua & 22.290 \\
\hline 33 & West Papua & 11.740 \\
\hline 34 & North Kalimantan & 11.428 \\
\hline
\end{tabular}

Unfortunately, the distribution of DCA has not been evenly distributed even though the number of channeling banks has been increasing. According to Irene Swasuyani, increasing the number of DCA distributions in Eastern Indonesia needs to be accompanied by adequate infrastructure. Obviously, it requires a lot of costs as stated by Irene Swasuyani, "However, this is still facing a cost constraint. The cost of distributing the DCA for MSMEs in Eastern Indonesia requires IDR 18 billion. This is because the process of distributing the DCA to MSMEs in Eastern Indonesia requires an air route. Thus, the number of DCA realizations in 2020 in Eastern Indonesia only reached 5 percent"'[13]

The table 1 above clearly defined that there are nine provinces in the eastern part of Indonesia whose total distribution has reached 100 thousand and above, including West Nusa Tenggara, South Sulawesi, East Nusa Tenggara, Bali, East Kalimantan, North Sulawesi, Central Sulawesi, South Kalimantan, West Kalimantan. Meanwhile, nine other provinces are categorized as very low DCA receiving areas namely, Central Kalimantan, West Sulawesi, Gorontalo, Maluku, North Maluku, Southeast Sulawesi, Papua, West Papua, and North Kalimantan. The province with the highest number of DCA recipients is West Java with a total distribution of 2,402,932, while the least number is North Kalimantan with only 11,428 MSMEs.

If we analyze the number of DCA recipients in Indonesia by using the Objective-Oriented Evaluation Approach, it can be concluded that the DCA program has achieved its target well. In 2020, the distribution target is 12.8 million. However, due to time constraints in which this program was carried out for only four months and at that time the program was still newly established, there was some remaining aid that was returned to the government. Nevertheless, the number of DCA distributions in 2020 has reached more than 50 percent of the total initial target. Meanwhile, in early
2021 this assistance has been distributed faster, around 9.8 million MSMEs already received the DCA before May. Analyzing its performance, this program shows a fairly good performance. Even though it is formed urgently during the COVID-19 pandemic [13].

\subsection{Direct Cash Assistance Program in SWOT analysis}

The Study Report of the Micro Business Capital Assistance Program (2020) conducted by the Fiscal Policy Agency of the Ministry of Finance also summarizes some of the advantages of this program such as cash assistance so that it can be directly used by MSME actors, the terms and criteria apply relatively easily, encouraging financial literacy because the recipient is required to have a bank account to disburse cash assistance, and there is an absolute liability letter (SPTJM) as proof that the recipients are MSMEs [14].

Weaknesses of the program are difficulty in obtaining MSMEs data, limited state budget, difficulty in verification, moral hazard (just starting a business to get assistance), difficulties in evaluating the use of funds, the number of applications that are less or more than the quota and the length of time for submission. In addition, Sri Haryati (DKI Jakarta Bureau of Economics and Finance) also added that several procedures were needed to improve, namely, involving further stakeholders to select and ensure that prospective beneficiaries really need assistance, where previously the DCA distribution process was directly end to end user from the Ministry of Cooperatives and SMEs [13].

If analyzed through the SWOT method, this study shows that the DCA program has several opportunities. First, it has encouraged digital acceleration and encouraged the initiation of stakeholders to compile data on Indonesian MSMEs which were previously quite disorganized. Second, encourage economic growth by improving the demand side through cash assistance. And third, encourage Regional Apparatus Work Units to work optimally in the recovery of MSMEs during the pandemic. Lastly, threats. These threats can come from external parties such as illegal fees taken from recipients and data theft [14]. In addition to that, based on the results of in-depth interviews with stakeholders, there is one main threat, namely, the lack of infrastructure that hinders DCA distribution in Eastern Indonesia [13].

\subsection{Prediction of Urban Migration in Indonesia in the Post Pandemic Era}

There are more than 45 percent of MSMEs in Indonesia facing difficulties in getting raw materials during the pandemic, so this condition has disrupted their production. Nine out of ten MSMEs faced lower demand for their products during the pandemic and many MSMEs also have difficulty in distributing their 
business products [15]. Therefore, the COVID-19 pandemic has had an impact on the production, consumption, and distribution processes.

The DCA Program can be regarded as a program for the recovery of MSMEs in Indonesia in the short term to be able to survive during the pandemic. However, this program has not been distributed evenly, especially in eastern Indonesia due to inadequate infrastructure. Due to the inequality distribution of DCA programs in Indonesia where the number of DCA realizations in 2020 in Eastern Indonesia only reached 5 percent, it is predicted that there will be an increase on Urban Migration for MSMEs in the post-pandemic era. In addition, this assistance scheme cannot be carried out all the time due to state budget constraints. Therefore, it is necessary to plan other programs or policies for the long term so that Indonesian MSMEs can survive and become robust after the pandemic. One of the steps that must be taken together is to create a business environment that supports the development of MSMEs [16].

There are three main factors which are causing urban migration, namely, economic, sociopolitical, and ecological. One of the strongest factors causing urban migration is the economic factor. Cities provide many career opportunities, as well as good income for workers. Not only that, infrastructure development in urban areas is also much better than in rural or remote areas. In the context of MSMEs, a larger population in urban areas will open up opportunities for MSME actors to market their products and services [17].

Based on statistical data.jakarta.go.id (2021), the number of people moving from villages to cities has been increased in 2020. For example, DKI Jakarta Province, the number of population arrivals reports from outside Jakarta is increasing, especially after Eid al-Fitr 2020. In May 2020, the total number was only 3,248 people. However, this number increased significantly to 10,363 people in June 2020 and 13,376 people in July 2020 [18].

This condition is one proof why the COVID-19 pandemic in Indonesia is not a barrier factor for villagers to carry out urbanization or urban migration. Researchers predict that in the post-pandemic era, the number of urban migration will also continue to increase. This is due to several factors. First, the COVID-19 pandemic has made MSMEs face difficulties in obtaining raw materials [19]. Second, health access is much easier to obtain in urban areas or in western Indonesia. Meanwhile, Eastern Indonesia still faces inequality in the availability of health facilities and health workers [20]. Conditions like this will be very risky for MSME actors if there is a health crisis such as the COVID-19 pandemic in the future.
Third, urban areas tend to have many assistance programs, especially when a crisis happen. For example, the DKI Jakarta Province has many assistance programs for MSMEs during the pandemic, including relaxation of IUMK [21], social assistance, Large-Scale Social Collaboration for MSMEs or Kolaborasi Sosial Berskala Besar [22], and the DCA program or BPUM. In the DCA program, DKI Jakarta ranks fifth as the province with the highest number of recipients (Table 1). This is also acknowledged by Frida Elizabeth (Department of Industry, Trade, Cooperatives, Small and Medium Enterprises, DKI Jakarta) that DKI Jakarta is one of the provinces with the most DCA recipients.

Lastly, the COVID-19 pandemic has driven the acceleration of digitization, including MSMEs. However, if the infrastructure in Eastern Indonesia is still uneven, then the MSME actors there will still find it difficult to increase the demand side through digital. This is similar to what was stated by [23] that long-term strategies in infrastructure such as, building digital technology and encouraging government collaboration with corporations in empowering MSMEs are very important. Because of these four factors, the researcher predicts that there will be a surge in urban migration in Indonesia particularly, in the post-pandemic era.

\section{CONCULSION}

The COVID-19 pandemic has not made urban migration in Indonesia to be declined. In fact, this number is increasing, one of which is the addition of residents from outside Jakarta city during the pandemic. MSMEs are the economic sector which closest to the community, especially the lower middle class. The policy of limiting activities that had never existed before in the two economic crises, namely, the Asian Financial Crisis and the Global Crisis made MSMEs stuck and experienced many obstacles such as constraints on supply, demand, difficulty in obtaining raw materials, distribution difficulties, and most importantly, the lack of cash flow so that MSMEs are in dire need of venture capital assistance.

By looking this condition, the Indonesian Government came up with the DCA Program. Unfortunately, the uneven condition of infrastructure makes it difficult for aid distributors to reach more MSMEs in need, especially in Eastern Indonesia. Equitable development needs to be the concern of all stakeholders so that the distribution of MSME assistance, access to health, and other supporting facilities can be evenly distributed. If this condition continues, it is feared that the level of urban migration will increase in the post pandemic era. Therefore, MSME assistance during the pandemic that is carried out evenly must be prioritized during the COVID-19 pandemic, because our focus is not only on growth but also economic recovery. 


\section{AUTHORS' CONTRIBUTIONS}

The first author contributed as the overall funding provider, drafted the concept, interviewed the stakeholders involved, and wrote the original draft. The second author contributed to data validation and data curation. Furthermore, the third author contributed to the review and editing of the journal manuscript.

\section{ACKNOWLEDGMENTS}

First and foremost, we would like to thank Irene Swa Suryani as Assistant Deputy for Financing, Ministry of Cooperatives and SMEs of the Republic of Indonesia for being the main resource person in this journal. Along with two other stakeholders who provided input regarding the DCA Program in DKI Jakarta as a comparison between aid distribution in urban areas and Eastern Indonesia as a whole, namely, Frida Elizabeth (Department of Industry, Trade, Cooperatives, Small and Medium Enterprises, DKI Jakarta) and Sri Haryati (DKI Jakarta Bureau of Economics and Finance).

\section{REFERENCES}

[1] Prasetyo, "Peran UMKM dlm Penanggulangan Kemiskinan \& Pengangguran (Prasetyo, 2008)," vol. 2, 2009.

[2] H. A. Sarwono, "Profil Bisnis Usaha Mikro, Kecil Dan Menengah (Umkm)," Bank Indones. dan LPPI, pp. 1-135, 2015.

[3] A. H. Putra, "Peran Umkm Dalam Pembangunan Dan Kesejahteraan Masyarakat Kabupaten Blora," J. Anal. Sosiol., vol. 5, no. 2, 2018, doi: 10.20961/jas.v5i2.18162.

[4] Mariyudi, "Success factors of SMEs: The case of Indonesia," Int. J. Bus. Innov. Res., vol. 19, no. 2, pp. 204-231, 2019, doi: 10.1504/IJBIR.2019.100074.

[5] S. Muslimah, "Penyelamat Krisis 1998, UKM Diharapkan Terjang Krisis Karena Corona." Jurnal.id.

https://www.jurnal.id/id/blog/penyelamat-krisis1998-ukm-diharapkan-terjang-krisis-karena-

korona/ (accessed Sept. 12, 2021)

[6] OJK, "Bagaimana UMKM \& Perbankan Dapat Sukses di Era Disrupsi Ekonomi dan Digital," pp. 1-108, 2020.

[7] D. Sugiri, "Menyelamatkan Usaha Mikro, Kecil dan Menengah dari Dampak Pandemi Covid19," Fokus Bisnis Media Pengkaj. Manaj. dan Akunt., vol. 19, no. 1, pp. 76-86, 2020, doi: 10.32639/fokusbisnis.v19i1.575.

[8] Siti Nur Aeni. "Bantuan UMKM: Syarat, Cara Daftar, Cek Penerima dan Pencairan BPUM." Katadata.co.id. https://katadata.co.id/sortatobing/finansial/60e6 dd521afe2/bantuan-umkm-syarat-cara-daftar- cek-penerima-dan-pencairan-bpum (accessed Sept. 11, 2021)..

[9] R. Rosita, "Pengaruh Pandemi Covid-19 Terhadap Umkm Di Indonesia," J. Lentera Bisnis, vol. 9, no. 2, p. 109, 2020, doi: 10.34127/jrlab.v9i2.380.

[10] A. K. Pakpahan, "Covid-19 Dan Implikasi Bagi Usaha Mikro, Kecil, Dan Menengah,” J. Ilm. Hub. Int., vol. 0, no. 0, pp. 59-64, 2020, doi: 10.26593/jihi.v0i0.3870.59-64.

[11] Tim Nasional Percepatan Penanggulangan Kemiskinan, Mempertahankan Usaha Mikro pada Masa Pandemi COVID-19. 2021.

[12] Luthfi Anshori, "Disusun Oleh: Disusun Oleh :," Anal. Pengaruh Aglomerasi, Urban. dan Investasi terhadap Ketimpangan Kabupaten/Kota di Provinsi Banten, vol. 1, no. 11150331000034, pp. 1-14, 2021, [Online]. Available: tnp2k.go.id.

[13] Irene Swasuyani, in-depth interview, May 2021.

[14] Badan Kebijakan Fiskal Kementerian Keuangan 2020 and Laporan, "PROGRAM BANTUAN MODAL."

[15] Shimomura UNDP Indonesia Resident Representative, "Impact of Pandemic on MSMEs in Indonesia,” p. 73, 2020.

[16] K. PPN/Bappenas, "Kajian Kebijakan Penanggulangan,” pp. 1-56, 2020.

[17] W. economic Forum, "Migration and Its Impact on Cities," J. World Econ. Forum, vol. 7, no. October, p. 172, 2017, [Online]. Available: http://www3.weforum.org/docs/Migration_Impa ct_Cities_report_2017_low.pdf\%0Afile:///C:/Us ers/Endalk/Desktop/Migration 2020/PhD proposal/pdf/Migration_Impact_Cities_report_2 017_low.pdf.

[18] A. Firmanita, "Minat Penduduk dari Luar DKI Jakarta untuk Datang ke DKI Jakarta pada Masa Pandemi COVID-19.” Statistik.jakarta.go.id. https://statistik.jakarta.go.id/minat-pendudukdari-luar-dki-jakarta-untuk-datang-ke-dkijakarta-pada-masa-pandemi-covid-19/ (accessed Sept. 19, 2021).

[19] D. R. Tairas, "COVID-19 Pandemic and MSMEs: Impact and Mitigation," Lect. Notes Bus. Inf. Process., vol. 402, no. 1, pp. 657-670, 2020, doi: 10.1007/978-3-030-63396-7_44.

[20] M. Misnaniarti et al., "Ketersediaan Fasilitas dan Tenaga Kesehatan Dalam Mendukung Cakupan Semesta Jaminan Kesehatan Nasional," J. Penelit. dan Pengemb. Pelayanan Kesehat., vol. 1, no. 1, pp. 6-16, 2018, doi: 10.22435/jpppk.v1i1.425.

[21] Yustinus Paat. "Pemprov DKI Terbitkan 105.000 Izin UMKM di Masa Pandemi." Beritasatu.com.

https://www.beritasatu.com/megapolitan/70217 9/pemprov-dki-terbitkan-105000-izin-umkm-dimasa-pandemi (accessed Sept. 19, 2021). 
[22] P. P. D. Jakarta, Mike Nafizahni. “Tiga Program Bantuan Pemprov DKI Jakarta selama Pandemi COVID-19." Corona.jakarta.go.id. https://corona.jakarta.go.id/id/artikel/tigaprogram-bantuan-pemprov-dki-jakarta-selamapandemi-covid-19 (accessed Sept. 15, 2021).

[23] D. Indonesia, W. C. Anggraeni, W. P. Ningtiyas, M. Alimah, and U. M. Malang, "Journal of Government and Politics Government Policy in Empowering SMEs during the Covid-19 Pandemic in Indonesia," vol. 3, no. 1, pp. 47-65, 2021. 